\title{
Capital Budgeting Technique Selection through Four Decades: With a Great Focus on Real Option
}

\author{
Maral Ghahremani ${ }^{1}$, Abdollah Aghaie ${ }^{1} \&$ Mostafa Abedzadeh ${ }^{1}$ \\ ${ }^{1}$ Department of Industrial Engineering, K. N. Toosi University of Technology, Tehran 143344, Iran \\ Correspondence: Abdollah Aghaie, Department of Industrial Engineering, K. N. Toosi University of Technology, \\ No. 7, Pardis St., MollaSadra Ave. Tehran 143344, Iran. Tel: 98-21-8406-3363. E-mail: AAghaie@kntu.ac.ir
}

\author{
Received: July 14, 2012 Accepted: August 15, $2012 \quad$ Published: September 1, 2012 \\ doi:10.5539/ijbm.v7n17p98 URL: http://dx.doi.org/10.5539/ijbm.v7n17p98
}

\begin{abstract}
Capital budgeting investment decisions involve the use of a large portion of a firm's assets; actually no decision places a company in more jeopardy than these decisions. Often these investments can cost billions of dollars, and require predictions of the future, without a suitable return the very existence of the company can be compromised.

This paper aims to provide a review and analysisoncapital budgeting techniquesfrom 1970 to 2012 in developing and developed countries regarding the most effective factors on selecting techniques. It also analyzes how industries proceed to more sophisticated techniques during four decades. The most important flaws of traditional methods were criticized to analyze whether adopting a new sophisticated method like real option (RO) could eliminate them. Through an overview on RO domain and its process, the most efficient usageof sophisticated methodswas found.Reviewing previous empirical studies on real option adoptiongive us insight for providing required infrastructures before applying real option process. Our main aim by providing this paperis to help readers makethe most appropriate decision about capital budgeting techniques in terms of different factors with a great focus on real option (in the case which real option domain would not be contravened)and fault detecting to remove important obstacles and achieve successful real option implementation.
\end{abstract}

Keywords: strategic investment decision, capital budgeting techniques, real option, risk management

Strategic investment decision making involves the process of identifying, evaluating, and selecting among projects that are likely to have a big impact on a company's competitive advantage (Ralph. W. Adler 2000).In Buckley viewpoint (1998), strategic projects represent the core of corporate growth, change and wealth creation. They are major investments, often involving high uncertainty. They comprise intangible benefits and promise attractive long-term financial outcomes (as cited in Asrilhant, Dyson, Meadows; 2004). Strategic projects also motivate the creation, acquisition and development of competencies (Foss, 1997), comprise a collection of diverse options (Amram and Kulatilaka, 1999), and must be conducted in a changeable, uncertain and complex environment (Kaplan and Norton, 1992; Partington, 2000).

The concept of real options (RO) has been around for more than three decades, many researchers put it in capital budgeting methods classification.Some think it is a strategic decision making tool, while other believe real options can serve not simply as an analytical tool but as a way of thinking and as an organizational process. Today, there are numerous books (e.g., Pyndick \& Dixit, 1994; Amram\&Kulatilaka, 1999; Chance \& Peterson, 2002; Mun, 2002; Kodulula \& Papudesu, 2006; Guthrie, 2009) and hundreds of published articles on real options and advantages in increasing project's value through management flexibility.

Although a great attention is concentrated on the subject of real options inacademy, due to previous surveystop managers do not appear to share this increasing interest in adopting real options. As Chance and Peterson (2002) noted, "Empirical research has provided some, but very limited, support for the real-world applicability of real options models."

In this paper, a comprehensive overview and analysis of capital budgeting practices has been conducted which represent the most used capital budgetingmethods(including real option) all around the world, and the most important reason for adoption or do not adoption. It is organized as follow. In Section 2 literature relevant to the 
capital budgeting practices including real option valuation is reviewed. Section 3 mentions the most important deficiencies of traditional methods and potential benefits of real option logic torecover them,Section 4 notes RO domain, application and it's process, Section 5 comprises overviewing someprevious surveys and paperson RO adoption. In this section industries, uncertain parameters, options, and reasons for adopting are assessed, and section 6 provides summery and conclusions.

\section{Literature Review of Capital Budgeting Practices}

A lot of surveys have been done all around the world about capital budgeting practices and the most effective factors on investment appraisal technique's selection. Numerous authors have assessed adoption of DCF methods in investment appraisal (e.g.: Boersema (1978), Rosenblatt and Jucker (1979), Aggarwal (1980), Ross (1986) in America and Sangster (1993) in the UK).

One of the good one was presented In1969 by Mao. He compared capital budgeting in theory and practice. In his survey, among eight companies which questioned about most used capital budgeting techniques, following result were found (table 2.1). He said "Payback period is primarily a risk measure.Accountingprofit is especially important if the company is widely held and relies on external sources of financing. Internal rate of return is most likely to be the major criterion in closely held firms which are less worried by erratic patterns in their per share earnings, which finance themselves and which make many small investments so that the risk in any one investment is not critical."

Table 2.1. Most used capital budgeting techniques

\begin{tabular}{cll}
\hline No & \multicolumn{1}{c}{$\begin{array}{c}\text { Most used techniques in } \\
\text { practice }\end{array}$} & \multicolumn{1}{c}{ Characteristic of companies } \\
\hline 2 & Internal rate of return & $\begin{array}{l}\text { Growth companies with closely held stock which finance growth } \\
\text { through internal generation of funds and whose typical investment } \\
\text { are small in relation to the total resources of the firm }\end{array}$ \\
4 & $\begin{array}{l}\text { Internal rate of return, } \\
\text { payback period and } \\
\text { accounting profit }\end{array}$ & $\begin{array}{l}\text { Publicly held companies which rely heavily on external sources to } \\
\text { finance growth and whose businesses are fairly risky and } \\
\text { competitive } \\
\text { They are similar to the above four in terms of stock ownership and } \\
\text { in their reliance on outside capital, but their investments are more } \\
\text { risky because of strong industry competition and because of their } \\
\text { few, but large investments. }\end{array}$ \\
\hline
\end{tabular}

Along these surveys Pike (1996) reported the findings of a longitudinal capital budgeting study based on surveys conducted between 1975 and 1992 compiled by conducting cross-sectional surveys on the same firms at approximately five year's intervals. He drew a sample of 208 firms from the largest 300 UK quoted companies as measured by market capitalization then he represented his findings in table 2.2. He believed that increased awareness of the time-value of money in decision making and increasing use of computer spreadsheets may have assisted in using NPV rapid growth. Although there had been a clear movement toward greater sophistication, the increase was significantly greater for larger firms than for smaller ones he stated that, this does not necessarily mean that it is company size that determines the degree of capital budgeting sophistication in firms. But the use of computers in capital budgeting was a powerful moderating variable in explaining sophistication levels. 
Table 2.2. Investment evaluation procedures and techniques (100 large firms) (Pike; 1996)

\begin{tabular}{|c|c|c|c|c|}
\hline Evaluation techniques (\%) & 1975 & 1980 & 1986 & 1992 \\
\hline A specific search and screening the alternatives & 76 & 84 & 98 & 100 \\
\hline A formal financial evaluation & 93 & 95 & 100 & 100 \\
\hline Payback & 73 & 81 & 92 & 94 \\
\hline Average accounting rate of return & 51 & 49 & 56 & 50 \\
\hline Internal rate of return & $44 *$ & $57 *$ & $75^{*}$ & $81^{*}$ \\
\hline Net present value & 32 & 39 & $68^{*}$ & $74 *$ \\
\hline \multicolumn{5}{|c|}{ Note: ${ }^{*}$ size a significant factor in degree of use at the $5 \%$ level } \\
\hline \multicolumn{5}{|c|}{ Combined evaluation techniques } \\
\hline Evaluation techniques (\%) & 1975 & 1980 & 1986 & 1992 \\
\hline No methods & 2 & 0 & 0 & 0 \\
\hline \multicolumn{5}{|l|}{ A single methods } \\
\hline PB & 14 & 12 & 6 & 4 \\
\hline AARR & 12 & 7 & 0 & 0 \\
\hline IRR & 5 & 4 & 2 & 0 \\
\hline \multirow[t]{2}{*}{ NPV } & 0 & 1 & 0 & 0 \\
\hline & 31 & 24 & 8 & 4 \\
\hline \multicolumn{5}{|l|}{ Two methods } \\
\hline PB/AARR & 14 & 13 & 10 & 8 \\
\hline PB/IRR & 14 & 15 & 8 & 9 \\
\hline $\mathrm{PB} / \mathrm{NPV}$ & 4 & 6 & 5 & 6 \\
\hline AARR/IRR & 0 & 2 & 2 & 0 \\
\hline AARR/NPV & 1 & 1 & 1 & 0 \\
\hline \multirow[t]{2}{*}{ NPV/IRR } & 1 & 4 & 3 & 5 \\
\hline & 34 & 41 & 29 & 28 \\
\hline \multicolumn{5}{|l|}{ Three methods } \\
\hline PB/AARR/IRR & 7 & 10 & 5 & 5 \\
\hline PB/AARR/NPV & 4 & 4 & 3 & 1 \\
\hline PB/IRR/NPV & 10 & 9 & 21 & 26 \\
\hline \multirow[t]{2}{*}{ AARR/IRR/NPV } & 1 & 1 & 0 & 0 \\
\hline & 22 & 24 & 29 & 32 \\
\hline \multicolumn{5}{|l|}{ Four methods } \\
\hline PB/AARR/IRR/NPV & 11 & 12 & 34 & 36 \\
\hline Total & 100 & 100 & 100 & 100 \\
\hline AARR: Average accounting rate of return & \multicolumn{4}{|c|}{ PB: Payback } \\
\hline IRR: Internal rate of return & \multicolumn{4}{|c|}{ NPV: Net present value } \\
\hline
\end{tabular}

He also assessed the risk analysis trends in his work and as represented in table 2.3 the sharpest trend in capital budgeting practices which had been found by pike was the formal analysis of risk; usage rates had moved from 26 percent in 1975 to 92 percent in 1992.

Table 2.3. Risk appraisal techniques- trend (response: 98 companies)

\begin{tabular}{lcccc}
\hline Firms which: & 1975 & 1980 & 1986 & 1992 \\
\hline Shorten payback period & 25 & 30 & 61 & 60 \\
Raise required rate of return & 37 & 41 & 61 & 65 \\
Use probability analysis & $9 *$ & $10^{*}$ & $40^{*}$ & 48 \\
Use sensitivity analysis & $28^{*}$ & $42^{*}$ & 71 & $88^{*}$ \\
Use beta analysis & 0 & 0 & 16 & $20^{*}$ \\
Note : ${ }^{*}$ size a significant factor in degree of use at the 5\% level & & & &
\end{tabular}

In this regard, the emphasis on risk assessment along with frequency of PB technique usage (which exploiting short term benefit with limiting risk through shortening investment period)so dominant over the past two 
decadeshave represented the complex, changeable and uncertain environment and necessity of project risk management.

In 2001Two surveys have been done on capital in two different companies, one of them formed in china by Chan et al and the other by Graham \& Harvey in U.S.

Chan et al (2001) set a survey like previous onesabout popularity of appraisal methods among Chinese firms. They classified appraisal techniques into primary and secondary, the result of their research is presented in table 2.4.

Table 2.4.

\begin{tabular}{lcc}
\hline Capital budgeting techniques & $\begin{array}{c}\text { Primary } \\
\text { percent }\end{array}$ & $\begin{array}{c}\text { Secondary } \\
\text { percent }\end{array}$ \\
\hline Net present value (NPV) & 88.9 & 11.1 \\
Internal rate of return (IRR) & 40.7 & 57.4 \\
Payback period & 13 & 83.3 \\
Discounted payback period & 18.5 & 70.4 \\
Profitability index & 46.3 & 46.3 \\
Accounting rate of return (book rate of return on asset) & 66.7 & 27.8 \\
Modified internal rate of return & 14.8 & 64.8 \\
\hline
\end{tabular}

They also asked questions concerning if and how risk was taken into account when evaluating projects. Over fifty percent of the firms indicated they did specifically differentiate project risk by either grouping projects into risk classes or individually measuring project risk then the methods used in this regard were assessed. Their Results are shown in table 2.5.

Table 2.5

\begin{tabular}{lc}
\hline Methods for adjusting for risk & Percent \\
\hline Risk - adjust the cash flows of each project & 37 \\
Risk - adjust the cost of capital applied to each project & 29.6 \\
Risk - adjust both the cash flows and the cost of capital & 33.3 \\
Total & 100 \\
\hline
\end{tabular}

On the other hand Graham \& Harvey (2001) pick up their respondents from Fortune 500 companies' financial officers \& members of the Financial Executives Institute. They conducted a comprehensive survey analyzing the current practice of corporate finance. They used both simple, traditional and advanced, sophisticated appraisal techniques in their survey. They most focused on cost of capital and methods determining discount rate. Their result has shown in figure 2.1 . 


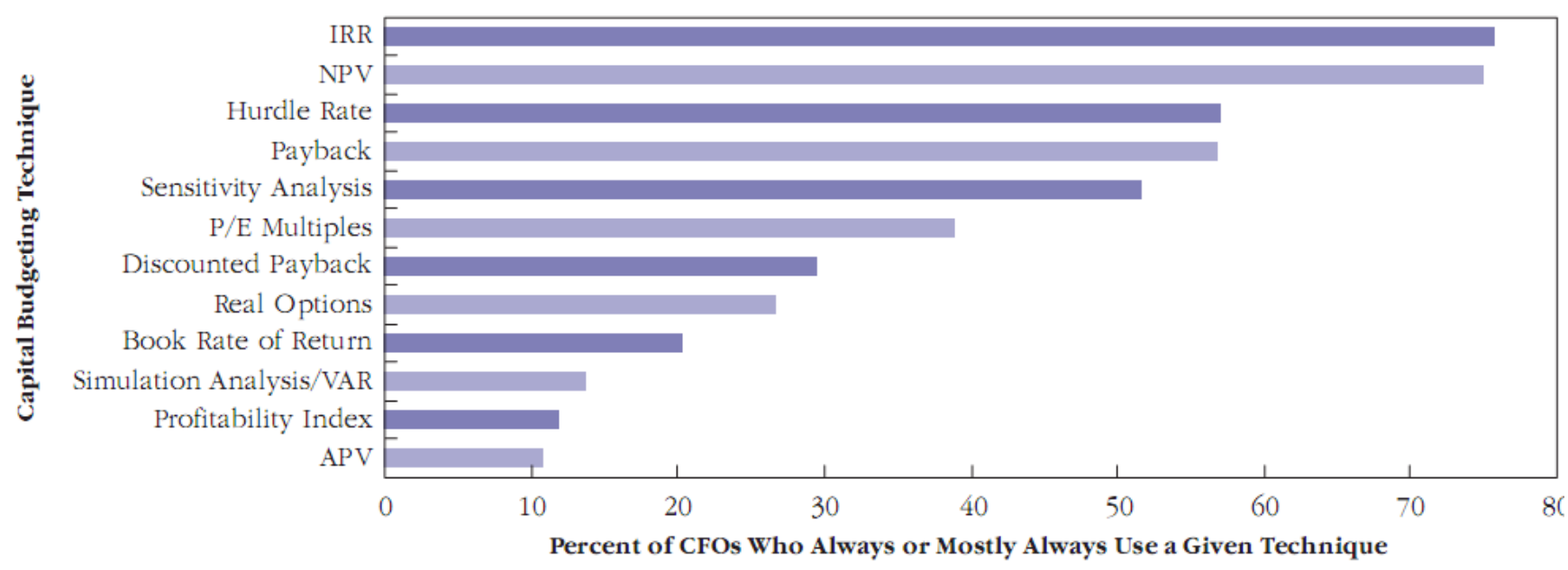

Figure 2.1 Popularity of capital budgeting techniques (Graham \& Harvey; 2001)

Although comparing two surveys on two different sample,cultures and in different geographical locations do not seem true, but we could see in Graham \& Harvey's study, some new, advanced and sophisticated methods (like simulation, VAR and real option) evaluated among these firms. Thus the differences in practice of corporate finance may be attributed to diversity of institutional systems and languages, the level of economic, financial, and human capital developments ofdifferent countries.

Almost the same study had been done by Ryan\& Ryan in 2002, examining the capital budgeting decision methods used by the Fortune 1000 companies. They classified their sample corresponding to size of annual capital budget. The results in table 2.6 show that NPV and IRR had been preferred over all other capital budgeting methods. It was a notable alignment of theory and practice for the first time.Descending order of PB adoption and ascending order of IRR and ARR adoption regarding to size of capital budget represent using more precise and accurate methods when corporations deal with high capital budget size. They also set a same format for asking use of more specialized and advanced methods, results in table 2.7 showed that some of them like Economic Value Added (EVA) and Market Value Added (MVA) models had received strong acceptance and usage despite the relative youth of the methods.Increased focus on investment risk management, increased use of supplementary methods and risk assessment methods, led companies into a more sophisticated investment appraisal approaches considering risk and uncertainty through assessment. 
Table 2.6. Relative usage of various capital budgeting tool (Ryan \& Ryan; 2002)

Responses to the question:" please classify how frequently your firm utilizes each of the following budgeting tools: "often" would generally mean that you use this tool about $75 \%$ of the time, "sometimes" would refer to about $50 \%$, and "rarely" would mean about $25 \%$ of the time. The absolute percentages are in column 3-7 and cumulative percentages are in column $8-10$

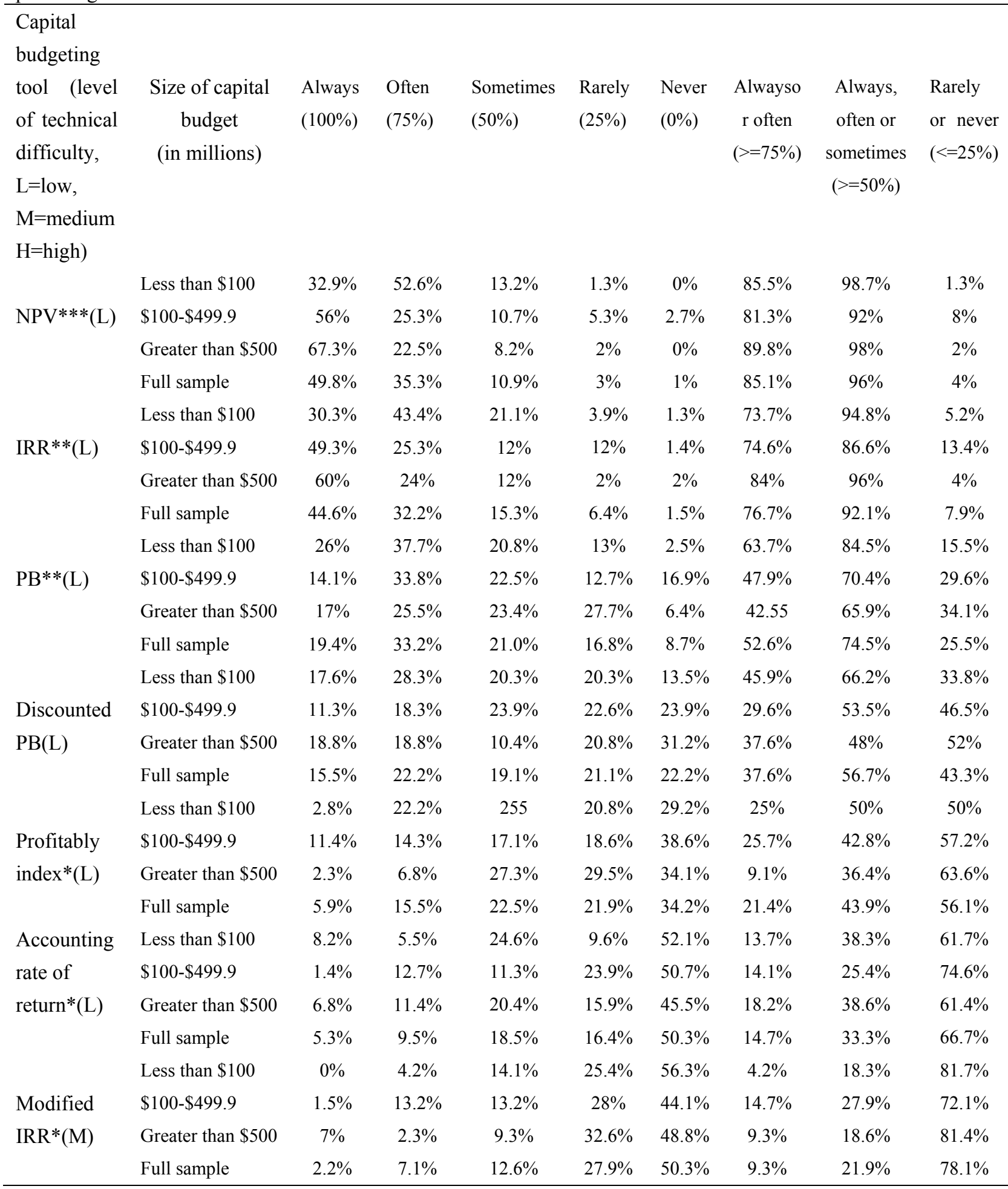


Table 2.7. Relative usage of various supplementary capital budgeting tool (Ryan \& Ryan; 2002)

Responses to the question:" please classify how frequently your firm utilizes each of the following budgeting tools: "often" would generally mean that you use this tool about $75 \%$ of the time. "sometimes" would refer to about $50 \%$, and "rarely" would mean about $25 \%$ of the time. The absolute percentages are in column 2-6 and cumulative percentages are in column 7-9

\begin{tabular}{|c|c|c|c|c|c|c|c|c|}
\hline $\begin{array}{l}\text { Supplemental Capital } \\
\text { budgeting tools* (level } \\
\text { of technical difficulty, } \\
\mathrm{L}=\text { low, } \quad \mathrm{M}=\text { medium } \\
\mathrm{H}=\text { high) }\end{array}$ & $\begin{array}{l}\text { Always } \\
(100 \%)\end{array}$ & $\begin{array}{l}\text { Often } \\
(75 \%)\end{array}$ & $\begin{array}{l}\text { Sometimes } \\
(50 \%)\end{array}$ & $\begin{array}{l}\text { Rarely } \\
(25 \%)\end{array}$ & $\begin{array}{l}\text { Never } \\
(0 \%)\end{array}$ & $\begin{array}{l}\text { Always or } \\
\text { often } \\
(>=75 \%)\end{array}$ & $\begin{array}{c}\text { Always, } \\
\text { often or } \\
\text { sometimes } \\
(>=50 \%)\end{array}$ & $\begin{array}{l}\text { Rarely or } \\
\text { never } \\
(<=25 \%)\end{array}$ \\
\hline Sensitivity analysis (M) & $20.5 \%$ & $44.6 \%$ & $20 \%$ & $4.1 \%$ & $10.8 \%$ & $65.1 \%$ & $85.1 \%$ & $14.9 \%$ \\
\hline Scenario analysis $(\mathrm{M})$ & $10.5 \%$ & $31.1 \%$ & $25.3 \%$ & $12.1 \%$ & $21.1 \%$ & $41.6 \%$ & $66.8 \%$ & $33.2 \%$ \\
\hline $\begin{array}{l}\text { Inflation adjusted cash } \\
\text { flows (M) }\end{array}$ & $12 \%$ & $19.4 \%$ & $15.2 \%$ & $25.1 \%$ & $28.3 \%$ & $31.4 \%$ & $46.6 \%$ & $53.4 \%$ \\
\hline $\begin{array}{l}\text { Economic value added } \\
(\mathrm{EVA})(\mathrm{M})\end{array}$ & $12 \%$ & $18.8 \%$ & $23 \%$ & $19.9 \%$ & $26.2 \%$ & $30.9 \%$ & $53.9 \%$ & $46.1 \%$ \\
\hline Incremental IRR(M) & $8.5 \%$ & $19.1 \%$ & $19.7 \%$ & $16.5 \%$ & $50.3 \%$ & $27.7 \%$ & $47.3 \%$ & $52.7 \%$ \\
\hline simulation $(\mathrm{H})$ & $3.1 \%$ & $16.2 \%$ & $17.8 \%$ & $27.2 \%$ & $35.6 \%$ & $19.4 \%$ & $37.2 \%$ & $62.8 \%$ \\
\hline $\begin{array}{l}\text { Market value added } \\
(\mathrm{MVA})(\mathrm{M})\end{array}$ & $3.7 \%$ & $11.2 \%$ & $18.1 \%$ & $26.6 \%$ & $40.4 \%$ & $14.9 \%$ & $33 \%$ & $67 \%$ \\
\hline PERT/CPM(M) & $1.1 \%$ & $7.1 \%$ & $22.8 \%$ & $26.1 \%$ & $42.9 \%$ & $8.2 \%$ & $31 \%$ & $69 \%$ \\
\hline Decision tree $(\mathrm{M})$ & $1.1 \%$ & $6.8 \%$ & $23.2 \%$ & $33.7 \%$ & $35.3 \%$ & $7.9 \%$ & $31.1 \%$ & $68.9 \%$ \\
\hline $\begin{array}{l}\text { Complex mathematical } \\
\operatorname{method}(\mathrm{H})\end{array}$ & $1.1 \%$ & $6.9 \%$ & $13.5 \%$ & $22.2 \%$ & $56.8 \%$ & $7.6 \%$ & $21.1 \%$ & $78.9 \%$ \\
\hline Linear programming $(\mathrm{H})$ & $0 \%$ & $5.4 \%$ & $11.4 \%$ & $23.2 \%$ & $60 \%$ & $5.4 \%$ & $16.8 \%$ & $83.2 \%$ \\
\hline $\begin{array}{l}\text { Option pricing model } \\
(\mathrm{H})\end{array}$ & $0 \%$ & $5.3 \%$ & $15.5 \%$ & $26.7 \%$ & $52.4 \%$ & $5.3 \%$ & $20.9 \%$ & $79.1 \%$ \\
\hline Real option $(\mathrm{H})$ & $0 \%$ & $1.1 \%$ & $9.7 \%$ & $23.2 \%$ & 65.4 & $1.6 \%$ & $11.4 \%$ & $88.6 \%$ \\
\hline
\end{tabular}

In Finland Liljeblom \& Vaihekoski (2004) conducted a survey among the publicly companies listed on the Finnish stock exchange. They sought the most commonly used investment evaluation methods, companies' approaches toward project specific rate of return and methods for projects' risk measurements. In 2006 same type research presented by Soni. He classified investment appraisal methods intothreesets: simple capital budgeting techniques (PB, ARR), advanced capital budgeting techniques (NPV, IRR) and sophisticated capital budgeting techniques (ROA, game theory) and conducted a survey about their popularity and importance. His research also comprised adopting risk analysis techniques among different companies and industries. His findings have been shown in table 2.8. In his opinion evidence was inconsistent to the proposition that the theory practice gap had narrowed considering improvements in financial knowledge among decision makers and technological developments. 
Table 2.8. Frequency of primary and secondary appraisal methods in India (Soni; 2006)

\begin{tabular}{lcccc}
\hline Evaluation technique & Primarily & $\%$ & Secondary & $\%$ \\
\hline Payback period & 5 & 5.7 & 54 & 62.1 \\
Accounting rate of return & 2 & 2.3 & 6 & 6.9 \\
Internal rate of return & 58 & 66.7 & 11 & 12.6 \\
Net present value & 8 & 9.2 & 6 & 6.9 \\
Break even analysis & 2 & 2.3 & 2 & 2.3 \\
Game theory & 1 & 1.1 & 1 & 1.1 \\
Real options pricing & 3 & 3.4 & 2 & 2.3 \\
Economic value added & 7 & 8 & 5 & 5.7 \\
Monte Carlo simulations & 1 & 1.1 & 0 & 0 \\
Non- financial criterion & 0 & 0 & 0 & 0 \\
Total & 87 & 100 & 87 & 100 \\
\hline
\end{tabular}

He also considered some non- financial criterion and the capital budgeting plans period in his work.As table 2.9 represents Most of respondent interested in short term investment.So by those evidences, lack of real option adoption has not been surprising.

Table 2.9. Usage of nonfinancial criterion \& future planning period

\begin{tabular}{lccccc}
\hline Nonfinancial criterion & No of companies & $\%$ & $\begin{array}{c}\text { Future planning } \\
\text { (years) }\end{array}$ & No & $\%$ \\
\hline Alignment with strategy & 47 & 54 & 1 & 4 & 4.598 \\
Culture fit & 15 & 17.2 & 2 & 14 & 16.09 \\
Augment skill range & 5 & 5.7 & 3 & 45 & 51.72 \\
Technology platform & 9 & 10.3 & 4 & 19 & 21.84 \\
building & & & & 5 & 5.747 \\
not used & 11 & 12.6 & $>4$ & \\
\hline
\end{tabular}

Among these researches, Block (2007) focused exclusively on real options and capital budgeting.In his survey of Fortune 1000 companies, the 40 users of real option came mainly from industries where sophisticated analysis was the norm, such as technology, energy, and utilities. Further, he foundthat industry classification had a significant relationship to the use of real options but did not have a significant relationship to the techniques used.We further represent his findings in section 5 .

More effective factors on capital budgeting were assessed in another study presented in 2008. Leon et al(2008) reported the results of a survey on executives from companies listed on the Jakarta Stock Exchange. They put companies from different age, different size and different industry in their sample. They also asked about overall objective of the capital budgeting process and mentioned factors influencing Capital Budgeting Practices as: Education Background of the Chief Financial Officer, Firm Size, Size of Annual Capital Investment, Type of Industry, Period of Listing, Type of Ownership and Financial Risk and classified the responses thorough these factors. You can see their results in table 2.10. 
Table 2.10. Profile of respondents (Leon et al; 2008)

\begin{tabular}{|c|c|c|c|c|c|}
\hline & \multicolumn{3}{|c|}{ Usage of capital budgeting technique } & \multirow[b]{2}{*}{$\mathrm{N}$} & \multirow{2}{*}{$\begin{array}{l}\text { Chi-square } \\
\text { significance }\end{array}$} \\
\hline & DCF & Non-DCF & Not used & & \\
\hline \multicolumn{6}{|c|}{ (a) Educational Level of the Respondents } \\
\hline No college or universityEducation & $13 \%$ & $50 \%$ & $37 \%$ & 8 & \multirow{2}{*}{0.08} \\
\hline $\begin{array}{l}\text { With University education } \\
\text { (b) Company Size (Total Asset) }\end{array}$ & $53 \%$ & $30 \%$ & $18 \%$ & 100 & \\
\hline Small & $56 \%$ & $22 \%$ & $22 \%$ & 36 & \multirow{3}{*}{0.948} \\
\hline Medium & $44 \%$ & $39 \%$ & $17 \%$ & 36 & \\
\hline Large & $50 \%$ & $33 \%$ & $17 \%$ & 36 & \\
\hline \multicolumn{6}{|c|}{ (c) Increase in Net Fixed Assets (Rp million) } \\
\hline$<50,000$ & $55 \%$ & $19 \%$ & $26 \%$ & $31 \%$ & \multirow{5}{*}{0.459} \\
\hline $50,000-199,999$ & $50 \%$ & $33 \%$ & $17 \%$ & $30 \%$ & \\
\hline $200,000-349,999$ & $27 \%$ & $64 \%$ & $9 \%$ & $11 \%$ & \\
\hline $350,000-499,999$ & $60 \%$ & $40 \%$ & $0 \%$ & $10 \%$ & \\
\hline$>=500,000$ & $50 \%$ & $27 \%$ & $23 \%$ & $26 \%$ & \\
\hline \multicolumn{6}{|l|}{ (d) Type of Industry } \\
\hline Agriculture & $25 \%$ & $75 \%$ & $0 \%$ & 4 & \multirow{8}{*}{0.208} \\
\hline Mining & $100 \%$ & $0 \%$ & $0 \%$ & 2 & \\
\hline Chemicals & $55 \%$ & $27 \%$ & $18 \%$ & 22 & \\
\hline Industrial Product & $36 \%$ & $43 \%$ & $21 \%$ & 28 & \\
\hline Consumer goods & $62 \%$ & $33 \%$ & $5 \%$ & 21 & \\
\hline Property and construction & $75 \%$ & $0 \%$ & $25 \%$ & 4 & \\
\hline Infrastructure and utilities & $80 \%$ & $0 \%$ & $20 \%$ & 5 & \\
\hline Trade and services & $41 \%$ & $27 \%$ & $32 \%$ & 22 & \\
\hline \multicolumn{6}{|l|}{ (e) Period of Listing (number of years) } \\
\hline$<5$ & $60 \%$ & $10 \%$ & $30 \%$ & 5 & \multirow{5}{*}{0.108} \\
\hline $5-9$ & $44 \%$ & $44 \%$ & $12 \%$ & 38 & \\
\hline $10-14$ & $44 \%$ & $31 \%$ & $26 \%$ & 41 & \\
\hline $15-19$ & $75 \%$ & $25 \%$ & $0 \%$ & 16 & \\
\hline$>=20$ & $44 \%$ & $22 \%$ & $34 \%$ & 8 & \\
\hline \multicolumn{6}{|l|}{ (f) Type of Ownership } \\
\hline Domestic company & $53 \%$ & $30 \%$ & $17 \%$ & 80 & \multirow[t]{2}{*}{0.679} \\
\hline Foreign company & $43 \%$ & $36 \%$ & $21 \%$ & 28 & \\
\hline \multicolumn{6}{|c|}{ (g) Financial Risk (Total Debt to Total Asset Ratio) } \\
\hline$<=0.40$ & $52 \%$ & $22 \%$ & $26 \%$ & 27 & \multirow{6}{*}{0.668} \\
\hline $0.41-0.55$ & $56 \%$ & $38 \%$ & $6 \%$ & 16 & \\
\hline $0.56-0.70$ & $52 \%$ & $33 \%$ & $15 \%$ & 33 & \\
\hline $0.71-0.85$ & $38 \%$ & $31 \%$ & $31 \%$ & 16 & \\
\hline$>0.85$ & $50 \%$ & $38 \%$ & $12 \%$ & 16 & \\
\hline $\mathrm{N}$ & 54 & 34 & 20 & 108 & \\
\hline
\end{tabular}

Developing investment appraisal techniques had much faster trend in theory comparing to practice. Regardless of criticism on traditional methods and emerging new and more efficientones, companies are still using traditional methods.Miliset al (2008) showed this gap in their work. Theyfound that although traditional capital investment appraisal techniques (CIAT's) such as payback period or net present value have been the most used techniques for assessing the feasibility of ICT investments but they were not the most efficient ones. They also reviewed adjusted techniques, new techniques like real option in their work and mentioned pros and cons for each method.

Daunfeldt \& Hartwig (2011) found out there were more effective parameters on technique selection. They examined the choice of capital budgeting methods used by companies listed on the Stockholm Stock Exchange (their results are shown in table 2.11). They told "the choice of capital budgeting methods is also influenced by leverage, growth opportunities, dividend pay-out ratios, choice of target debt ratio, and degreeof management ownership, foreign sales, industry, and individual characteristics of the CEO." 
Table 2.11. Popularity of capital budgeting methods in Sweden

\begin{tabular}{lllll}
\hline Capital budgeting method & $0-2$ & $\%$ & $3-4$ & $\%$ \\
\hline (a) Net present value method & 75 & $38.86 \%$ & 118 & $61.14 \%$ \\
(b) IRR-method & 135 & $69.95 \%$ & 58 & $30.05 \%$ \\
(c) Annuity method & 187 & $96.89 \%$ & 6 & $3.11 \%$ \\
(d) Earning multiple approach & 139 & $72.02 \%$ & 54 & $27.98 \%$ \\
(e) APV & 180 & $93.26 \%$ & 13 & $6.74 \%$ \\
(f) Payback method & 88 & $45.6 \%$ & 105 & $54.4 \%$ \\
(g) Discounted payback & 160 & $82.9 \%$ & 33 & $17.1 \%$ \\
(h) Profitability index & 169 & $87.56 \%$ & 24 & $12.44 \%$ \\
(i) Accounting rate of return & 147 & $76.17 \%$ & 46 & $23.83 \%$ \\
(j) Sensitivity analysis & 106 & $54.92 \%$ & 87 & $45.08 \%$ \\
(k) Value-at-risk & 180 & $93.26 \%$ & 13 & $6.74 \%$ \\
(l) Real option & 189 & $97.93 \%$ & 4 & $2.07 \%$ \\
Method never or occasionally (0-2) - frequently or always (3-4) & & & \\
\hline
\end{tabular}

They also made a comparison between the usage of capital budgeting techniques in Swedish companies and companies in U.S and continental Europe (figure 2.2).

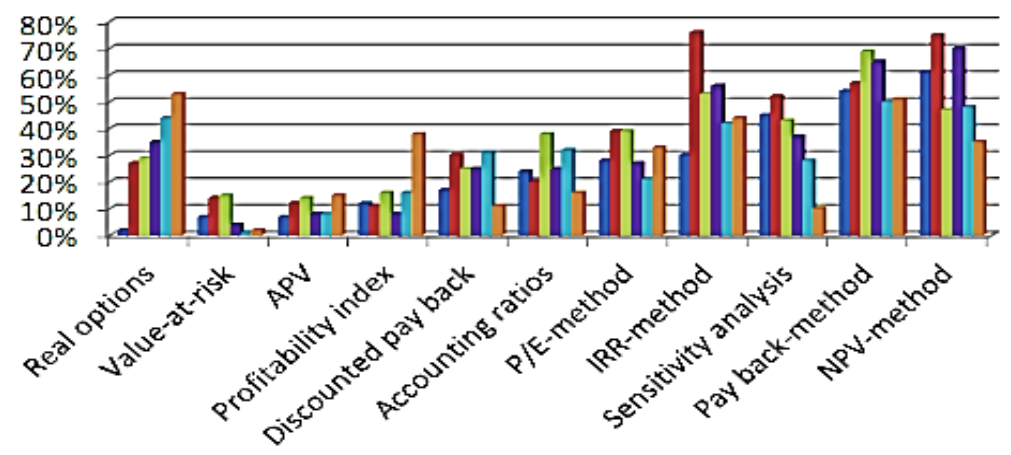

口 SWE $2005+2008(287 \%)$

口US (413\%)

口UK $(388 \%)$

Detherlands (360\%)

口 Germany (321\%)

$\square$ France (308\%)

Figure 2.2 Usage of capital budgeting techniques in Swedish companies and companies in U.S and continental Europe (Daunfeldt\&Hartwig; 2011)

Andoret al (2011), in their study reported the results from executives of companies in ten countries in Central and Eastern Europe (CEE) (Bulgaria, Croatia, Czech Republic, Hungary, Latvia, Lithuania, Poland, Romania, Slovak Republic, and Slovenia). In their study three factors have been assessed: firm size, multinational culture and insider ownership. They also made a comparison between the CCE and developed countries.

Baker et al (2010) assessed a large sample of Canadian firms to first learn whether they use real options, the types of real options used, and why firms do or do not use this method. We return to their results in section 5.

However 30 years passed from Real option logic emersion but as we can see adoption of RO as an investment appraisal technique have been very slow.So despite lots of researches have been done criticizing traditional methods we are going to investigate the most important ones and whether RO logic could cover them.

\section{What's Wrong with Traditional Approach? How Does Real Option Handle These Flaws?}

Traditional approaches to strategic investment appraisal, payback, accounting rate of return, return on investment (ROI), residual income, and discounted cash flow have been criticized on a number of grounds. Some of the chief criticisms are a too narrow perspective, exclusion of nonfinancial benefits, overemphasis on the short term, faulty assumptions about the status quo, inconsistent treatment of inflation, and promotion of non-value-adding behavior. 
First Investment proposals are often viewed through an exceedingly narrow decision-making lens, examined almost regularly from the sole perspective of the investing department. As such, the benefits that materialize outside that department (such as reductions in indirect labor and inventories) are often overlooked (Adler 2000) whereas structure of real option is enhancing value of projects through options valuation (e.g., expansion, contraction, abandonment and so on). Defining such specific options which assess and cover all decision features is impossible without providing experts from different corporation's units which develop dialogues between the various project stakeholders.

A second problem with the use of traditional appraisal techniques is their inability to account for the nonfinancial benefits that frequently characterize strategic investments. In particular, such issues as having greater manufacturing flexibility or being more efficient at providing information are seen as esoteric and are unable to fit into the financial calculus of traditional appraisal models.Likewise, terminal project values that is difficult to quantify, such as investments that pertain to system design, database development, or software, are commonly awarded a value of zero. But such an approach seems highly capricious and foolhardy, especially in light of growing evidence that these investments often provide invaluable organizational learning that can subsequently be applied to other projects (Adler 2000). On one handlack of real work applicability of RO restrict us from saying that ROV could cover this issue for sure, but there are some case studies which quantified nonfinancial benefits like $\mathrm{CO}_{2}$ emission reduction by assuming climate policy uncertainties innew energies and CCE technology valuation.So to some extent it is about appraisal team's abilityto make a combination of market and rival information, uncertainty and time fordiscoveringa proper option.On the other hand using nonfinancial benefits (which could subsequently be applied to other projects) is about long term capital budgeting plan which is the base of strategic decision making and also RO logic.

A third problem with traditional techniques adoption is in discounting cash flows, which benefits should be discounted at a market risk-adjusted discount rate like the WACC, but the investment cost should be discounted at a reinvestment rate similar to the risk-free rate. Cash flows that have market risks should be discounted at the market risk-adjusted rate, while cash flows that have private risks should be discounted at the risk-free rate. This is because the market will only compensate the firm for taking on the market risks but not private risks. It is usually assumed that the benefits are subject to market risks (because benefit free cash flows depend on market demand, market prices, and other exogenous market factors), while investment costs depend on internal private risks (such as the firm's ability to complete building a project in a timely fashion or the costs and inefficiencies incurred beyond what is projected)

In addition, because cash flows in the distant future are certainly riskier than in the near future, the relevant discount rate should also change to reflect this. Instead of using a single discount rate for all future cash flow events, the discount rate should incorporate the changing risk structure of cash flows over time (Mun, 2004). This can be done by real option structure which Payoff itself is adjusted for risk and then discounted at a risk-free rate and risk is expressed in the probability distribution of the payoff.

A fourth problem with traditional techniques is their short-term focus. Many strategic investments take many months, if not years, to become fully operational. The non-discounted cash flow (non-DCF) methods are particularly prone to this problem. They display an impatient regard for long lead times and snuff out such projects in their infancy. The payback method does this very explicitly by requiring very short payback periods, typically two to three years.

Meanwhile, accounting rate of return, ROI, and residual income prematurely kill investment ideas in a more subtle fashion. Managers who evaluateunder one of these latter three techniques are unlikely to invest in projects that require long lead times. The trend toward shorter job and company tenures means managers are never sure they will be around long enough to reap the benefits of their long-term investments.

Exactly why many firms insist on using such high costs of capital is unclear. It is likely, however, that they will be uncertain about the true risk of any particular strategic investment decision (SID). As a consequence, they may adopt a conservative approach that invariably leads to a higher cost of capital (Adler 2000). Long time characteristic of strategic investment and techniques required for considering this characteristic in evaluation were already discussed. Moreover traditional methods usually consider the downside risk of project than upside risk, thus they consider such high cost of capital to represent high level of risk or the risk aversion of investor but real option consider the life time of projects in several steps and then by limiting downside risk in each step and exploiting upside risk provide the most conservative approach in an uncertain environment.This could be used byevery investor with each risk acceptance level.

A fifth problem with traditional SID appraisal techniques is the assumptions that the current competitive position 
will remain unaltered if the investment is not undertaken. But this assumption is not necessarily true. It is only true if the cost, quality, flexibility, innovation features and special services offered by one's competitors also remain unchanged. Investors need an approach(real option) which could also consider an uncertain, competitive and dynamic condition.As mentioned above RO enhance value by evaluating different scenarios which are product of uncertainty, instability, and time and...

Yet a sixth problem is the inability to consider more than one source of uncertainty (which is represented in discount rate). In contrast with traditional SID appraisal techniques, RO could consider uncertainty in capital expenditure, cash flows, discount rate and so on.

Table 3.1 briefly represented these deficiencies.

Table 3.1. Overview traditional appraisal techniques \& real option

\begin{tabular}{|c|c|c|c|c|c|}
\hline & \multicolumn{4}{|c|}{$\begin{array}{l}\text { Most applied traditional } \\
\text { methods }\end{array}$} & \multirow{2}{*}{$\begin{array}{l}\begin{array}{c}\text { Real } \\
\text { option }\end{array} \\
\text { RO }\end{array}$} \\
\hline & PP & ROI & IRR & NPV & \\
\hline 1. Does it consider the entire lifetime of the investment? & no & Yes & yes & yes & yes \\
\hline 2. Does it consider the time value of money? & no & no & yes & yes & yes \\
\hline 3. Can risk-levels be entered into the feasibility evaluation? & no & Yes & yes & yes & yes \\
\hline $\begin{array}{l}\text { 4. Can risk - levels be entered in the selection of mutual exclusive } \\
\text { projects? }\end{array}$ & no & No & no & yes & yes \\
\hline $\begin{array}{l}\text { 5. Does it consider other department's perspectives except } \\
\text { investment department? }\end{array}$ & no & No & no & no & yes \\
\hline $\begin{array}{l}\text { 6. Does it consider non-financial benefits, intangible, or } \\
\text { immeasurable factors? }\end{array}$ & no & No & no & no & yes \\
\hline $\begin{array}{l}\text { 7. Can severalsource of uncertainty be entered into appraisal } \\
\text { process? }\end{array}$ & no & No & no & no & yes \\
\hline $\begin{array}{l}\text { 8. Does it consider managerial flexibility to alter the course of a } \\
\text { project? }\end{array}$ & no & No & no & no & yes \\
\hline 9. Does it mange project actively? & no & No & no & no & yes \\
\hline 10. Does it take into account behavioral and organizational biases? & no & No & no & no & no \\
\hline
\end{tabular}

Although some of previous problems to some extent could be eliminated through ROV but whether applying this approach in all the cases is conceivable, in next section we are going to argue about RO domain.

\section{Application Domain and RO Process}

Not all investment decisions can be framed as options. Four main conditions have to be fulfilled in order for a decision to be appropriate for real option logic: irreversibility, uncertainty, flexibility, and information revelation (Krychowski \& V. Quelin 2010).

In case of low degree of uncertainty and irreversibility, the NPV rule is more appropriate than RO (Adner \& Levinthal, 2004). Flexibility means that when the option expires, the firm really has the possibility to choose among several alternatives. If there is no other viable alternative, the investment project is a "bet", not an option.On the other hand, if the scope of opportunities is too wide, (either from a technological or from a market perspective) the decision process is more characterized by path dependence than by option logic. Whereas RO approach requires specifying ex-ante the possible project scenarios, exploration activities are difficult to anticipate (Krychowski \& V. Quelin, 2010)

Finally the condition of information revelation refers to the possibility of reducing uncertainty during the life of the option, either by observation or by investing in information acquisition.

Some application of real option:

- The area of natural resources investment(Renewable power generation technology, ...) 
- $\quad$ Land (Real Estate) development areas(Retaining land, ...)

- $\quad$ The field of corporate strategy( Joint venture, ...)

- $\quad$ The field of R \& D areas (Pharmaceutical R\&D projects, ...)

- $\quad$ The field of enterprise valuation (High-tech biotechnology companies, ...)

- Evaluation of regulation and policy's effects $\left(\mathrm{CO}_{2}\right.$ emission reduction policy, valuation of switchable tariff, ...)

- $\quad$ The field of supply chain management (multi-year procurement contract, ...)

\section{A Five Step Process}

Once the practitioner decides that ROA is the right tool for the project under consideration, a five step process can be used to calculate and analyze the option value for the project. (e.g., binomial method).

i. Frame the application: Framing a real option is more difficult than framing a financial option. It involves describing the problem in simple words and pictures, identifying the option, and stating clearly the contingent decision and the decision rule. Trigeorgis (1993) divided the real options into seven categories according to the differences in flexibility: Option to Defer, Staged Investment option, Option to Alter Operating Scale, Option to Abandon, Option to Switch, Growth Option, and Interacting Option. Some applications involve more than one decision or option. For example, chooser options may include abandon, defer, expand, contract, and other options. Compound options involve options on options, which may be parallel or sequential. You must identify these dependencies very clearly. Keeping the problem simple and making it more intuitive will help you communicate the results more effectively to get upper management's buy-in.

ii. Identify the input parameters: The basic input parameters (for the binomial method as an example) to value any type of option include the underlying asset value, strike price, option life, volatility factor, riskfree interest rate, and time increments to be used in the binomial tree. Additional information is required for some of the options, such as expansion and contraction options.

iii. Calculate the option parameters: The option parameters are intermediates to the final option value calculations and are calculated from the input variables (Kodukula \& Papudesu, 2006).

iv. Calculate the option value: Real options analysis (ROA) is far more complex compared to these traditional tools and requires a higher degree of mathematical understanding.There are several techniques to evaluate theoptions as shown in table 4.1.

v. Analyze the results: After the option value has been calculated, the appropriate first step is to compare the net present value derived from the DCF method versus ROA and evaluate the value added as a result of the flexibility created by the option(s).

Table 4.1 Option valuation techniques (Kodukula \& Papudesu; 2006)

\begin{tabular}{lcl}
\hline Option valuation techniques & Specific method \\
\hline Partial differential equations & - & Closed form solution using Black-Scholes and other similar \\
& & equations. \\
& - & Analytical approximations \\
& - & Numerical methods (finite difference method) \\
\hline Simulations & Monte & Carlo \\
\hline Lattices & - & Binomial \\
& - & Trinomial \\
& - & Multinomial \\
\hline
\end{tabular}

\section{Real Option in Practice: Reviewing Two Surveys on Applying Real Options}

Block (2007) conducted a survey of fortune 1000 companies whether they picked up RO to complement traditional analysis, application and percentagesof usage among industrieswere different. (table 5.1) 
Table 5.1. RO usage in different industries (Block; 2007)

\begin{tabular}{llll}
\hline Industries & No & Application fields & $\%$ \\
\hline Beverages & 3 & & \\
Energy & 25 & New product introduction & 36.2 \\
Finance & 31 & Research \& development & 27.8 \\
Food processing & 9 & Mergers or acquisitions & 22.1 \\
Health care & 26 & Foreign investment & 9.6 \\
Manufacturing & 57 & Other & 4.3 \\
Publishing & 5 & & 100 \\
Retail & 44 & & \\
Technology & 36 & & \\
Transportation & 12 & & \\
Whole sale & 9 & & \\
Utilities & 22 & & \\
& 279 & & \\
\hline
\end{tabular}

He also investigated the most used methods for solving real option. As table 5.2 represents Binomial lattice is the most popular approach in real option valuation due to simplicity of usage and explanation to top management.

Table 5.2. Techniques for using real option (Block; 2007)

\begin{tabular}{lc}
\hline Binomial lattices & 16 \\
Risk-adjusted decision trees & 12 \\
Monte Carlo simulation & 9 \\
Black-Scholes option pricing model & 1 \\
Other & 2 \\
& 40 \\
\hline
\end{tabular}

Baker et al (2010) also conducted a survey on a large number of Canadian firms to find out to what extent they apply RO in their appraisal process. (Table 5.3)

Table 5.3. Usage of Capital budgeting techniques (Baker et al; 2010)

This table presents managers' responses on which budgeting techniques Canadian firms use when deciding which projects or acquisitions to pursue based on a five-point frequency scale where $0=$ never, $1=$ rarely, $2=$ sometimes, $3=$ often, $4=$ always. Responses are ranked by their means from highest to lowest. The sample size is 214 . Percentages may not add up to 100 due to rounding.

\begin{tabular}{|c|c|c|c|c|c|c|c|c|}
\hline \multirow[b]{2}{*}{ S\# } & \multirow[b]{2}{*}{ Statement } & \multirow[t]{2}{*}{$\mathrm{N}$} & \multicolumn{4}{|c|}{ Frequency $(\%)$} & \multirow[b]{2}{*}{ Always } & \multirow[t]{2}{*}{ Mean } \\
\hline & & & Never & Rarely & Sometimes & Often & & \\
\hline 4 & Net present value & 214 & 14.4 & 4.2 & 6.8 & 25.4 & 49.2 & 2.93 \\
\hline 7 & Internal rate of return & 214 & 15.8 & 4.2 & 11.7 & 22.5 & 45.8 & 2.81 \\
\hline 2 & Payback & 210 & 12.1 & 2.6 & 18.1 & 28.4 & 38.8 & 2.78 \\
\hline 1 & $\begin{array}{l}\text { Accounting rate of } \\
\text { return }\end{array}$ & 213 & 40.5 & 7.8 & 12.1 & 14.7 & 25 & 1.76 \\
\hline 3 & Discounted payback & 213 & 56.4 & 7.7 & 11.1 & 11.1 & 13.7 & 1.18 \\
\hline 5 & Adjusted present value & 211 & 63.8 & 8.6 & 10.3 & 8.6 & 8.6 & 0.9 \\
\hline 6 & Profitability index & 210 & 78.4 & 5.2 & 5.2 & 6.9 & 4.3 & 0.53 \\
\hline 8 & $\begin{array}{l}\text { Modified internal rate } \\
\text { of return }\end{array}$ & 207 & 77.6 & 6.9 & 3.4 & 10.3 & 1.7 & 0.52 \\
\hline 9 & Real option & 211 & 80.9 & 4.3 & 4.3 & 6.1 & 4.3 & 0.47 \\
\hline
\end{tabular}


Through this study they asked participants to indicate whether their firms use each type of real options by responding "yes," "no," or "don't know and their results have been shown in figure 5.1.

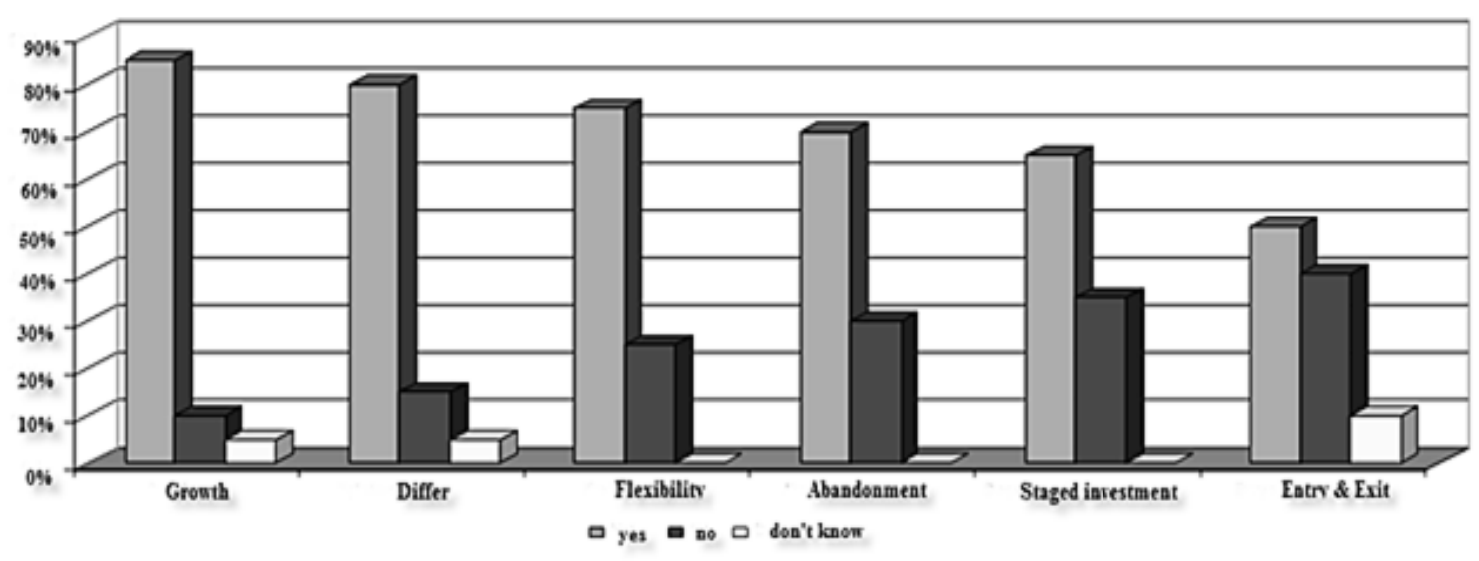

Figure 5.1. Usage of different type of real option (Baker; 2010)

Primary reasons that managers give for using or not using real option method represented in table $5.4 \& 5.5$.

Table 5.4. Why Canadian firms use ROV in capital budgeting decision (Baker et al; 2010)

\begin{tabular}{|c|c|c|c|c|c|c|c|}
\hline \multirow{3}{*}{ S\# } & \multirow{3}{*}{ Statement } & \multirow{3}{*}{$\mathrm{n}$} & \multicolumn{4}{|c|}{ Level of importance } & \multirow{3}{*}{ Mean } \\
\hline & & & None & Some & Moderate & High & \\
\hline & & & 0 & 1 & 2 & 3 & \\
\hline 6 & $\begin{array}{l}\text { Provides a management tool to help form } \\
\text { the strategic vision }\end{array}$ & 34 & 7.7 & 7.7 & 42.3 & 42.3 & 2.35 \\
\hline 1 & $\begin{array}{l}\text { Incorporates managerial flexibility into } \\
\text { the analysis }\end{array}$ & 36 & 5.6 & 11.1 & 55.6 & 27.8 & 2.06 \\
\hline 5 & $\begin{array}{l}\text { Provides a way of thinking about } \\
\text { uncertainty and its effect on valuation } \\
\text { over time }\end{array}$ & 35 & 9.1 & 9.1 & 45.5 & 36.4 & 2.05 \\
\hline 2 & $\begin{array}{l}\text { Complements traditional capital } \\
\text { budgeting techniques }\end{array}$ & 36 & 10 & 25 & 35 & 30 & 1.85 \\
\hline 4 & $\begin{array}{l}\text { Provides an analytical tool to deal with } \\
\text { uncertainty }\end{array}$ & 34 & 20 & 15 & 35 & 30 & 1.75 \\
\hline 3 & $\begin{array}{l}\text { Provides a long-term competitive } \\
\text { advantages through better decision } \\
\text { making }\end{array}$ & 36 & 25 & 15 & 30 & 30 & 1.65 \\
\hline
\end{tabular}


Table 5.5. Reasons Canadian firms do not use ROV (Baker et al; 2010)

\begin{tabular}{|c|c|c|c|c|c|c|c|}
\hline \multicolumn{8}{|c|}{$\begin{array}{l}\text { This table reports the reasons from } 169 \text { Canadian firms that do not use real options based on a four-point } \\
\text { importance scale where } 0=\text { none, } 1=\text { some, } 2=\text { =moderate, } 3=\text { high. Responses are ranked by their means from } \\
\text { highest to lowest. The sample size is } 169 \text {. Percentages may not add up to } 100 \text { due to rounding. }\end{array}$} \\
\hline \multirow{3}{*}{ S\# } & \multirow{3}{*}{ Statement } & \multirow{3}{*}{$\mathrm{N}$} & \multicolumn{4}{|c|}{ Level of importance(\%) } & \multirow{3}{*}{ Mean } \\
\hline & & & None & Some & Moderate & High & \\
\hline & & & 0 & 1 & 2 & 3 & \\
\hline 1 & Lack of expertise or knowledge & 166 & 12.6 & 9.5 & 15.8 & 62.1 & 2.27 \\
\hline 4 & Lack of applicability to our business & 161 & 55.9 & 7.5 & 15.1 & 21.5 & 1.02 \\
\hline 5 & Too complex to apply in practice & 163 & 52.2 & 9.8 & 22.8 & 15.2 & 1.01 \\
\hline 3 & Difficulty of estimating inputs & 164 & 60.9 & 7.6 & 19.6 & 12 & 0.83 \\
\hline 2 & Requires unrealistic assumptions & 163 & 64.1 & 8.7 & 18.5 & 8.7 & 0.72 \\
\hline 7 & $\begin{array}{l}\text { Does not help managers make better } \\
\text { decisions }\end{array}$ & 158 & 67.4 & 4.4 & 18.5 & 9.8 & 0.71 \\
\hline 8 & $\begin{array}{l}\text { Limited support for real-world } \\
\text { applicability of real option models }\end{array}$ & 153 & 64.8 & 9.1 & 18.2 & 8 & 0.69 \\
\hline 6 & Requires many internal resources & 159 & 63 & 15.2 & 14.1 & 7.6 & 0.66 \\
\hline
\end{tabular}

By comparing these reasons with block's survey, some other reasons for not using of RO such as : Lack of top management support, requiring too much sophistication, encouraging too much risk taking and popularity and acceptability of discounted cash flow method were observed. (table 5.6)

Table 5.6. Reasons firms do not use ROV (Block; 2007)

\begin{tabular}{ll}
\hline Lack of top management support & $42.7 \%$ \\
Discounted cash flow is a proven method & $25.6 \%$ \\
Requires too much sophistication & $19.5 \%$ \\
Encourages too much risk taking & $12.2 \%$ \\
& 100 \\
\hline
\end{tabular}

As far as we can see reasons mentioned by financial officers was chiefly about providing input data, organizational culture and complexity of solutions' process. As Adler (2000) said one trap managers must avoid is viewing the ease and cost of obtaining information as a reason for choosing or excluding particular investment appraisal techniques. Strategic investment decisions are too important not to receive a full and thorough examination, even if it means more time and expense. Because a firm's competitive fortunes will be affected by the decision made. Managers must remember that what truly matters is not the maximization of short term cash flow but the optimal positioning of the firm for the long run. In table 5.7 we briefly review some case study papers on real option: parameters and options considered, and solution methods applied through evaluation. 
Table 5.7. Review on some real option case studies

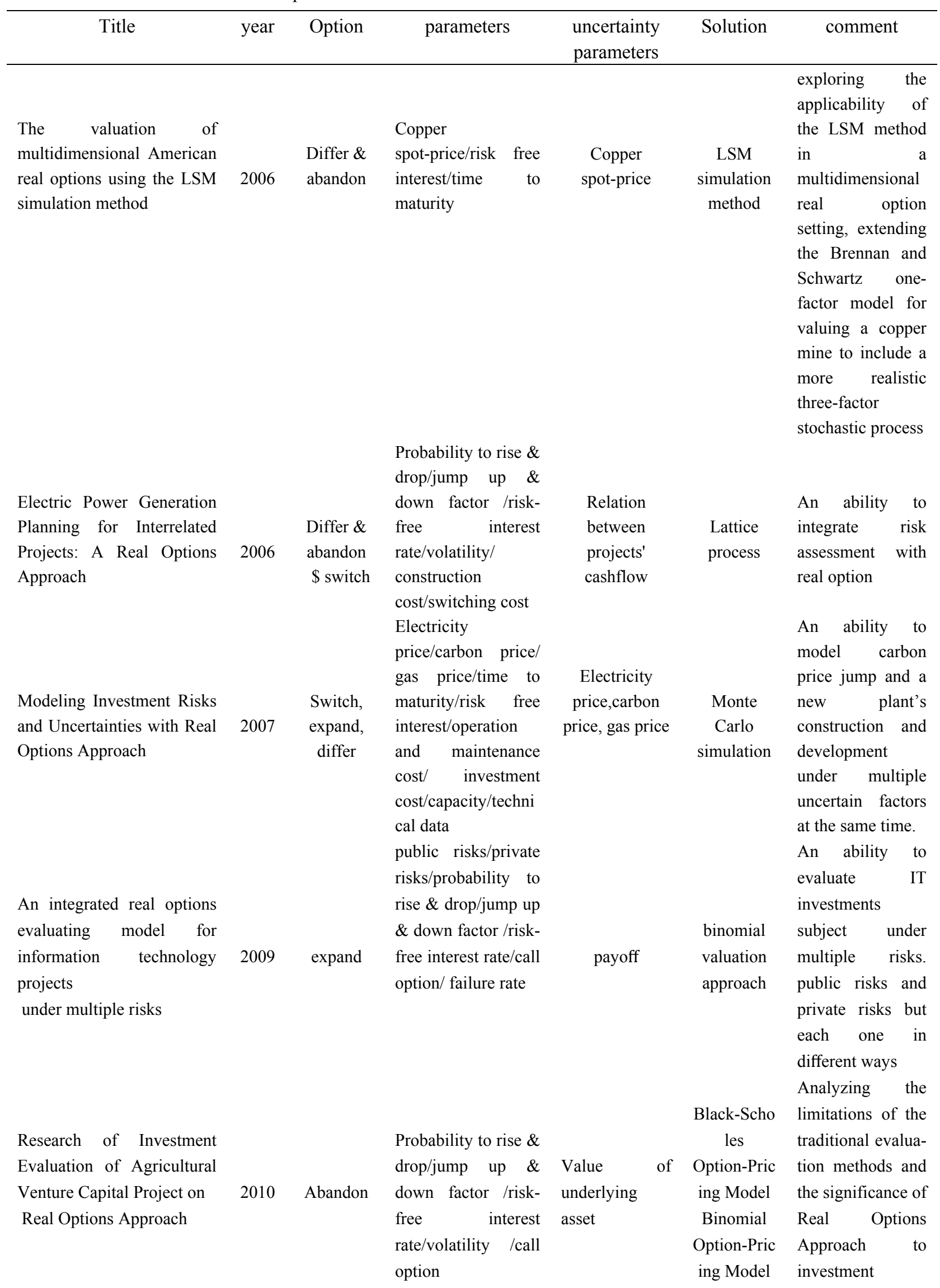


Valuing Investments in Distribution Networks with DG under Uncertainty
Using real option analysis for highly uncertain technology investments:

The case of wind energy technology
A real options-based CCS investment evaluation model: Case study of China's power generation sector
Growth rate of demand/cost of electricity

2010

production/availabil

\& ity of system's relocation elements/net income of distribution system operator/downside risk/, Weight

Average Cost of Capital/volatility of energy/fuel prices/correlations between areas/sortino rate

Risk-free interest 2011 Defer rate/volatility/value of underlying price/exercise price/time to maturity

$\mathrm{CO} 2$ emission reduction/existing thermal power generating cost/carbon price/ thermal power withCCS generating cost/timeto maturity /risk-free interest/technical data evaluation of

agricultural

venture capital projects.

Proposing an appraisal method for the quantitative

Bellman determination of the uncertainties that affect the distribution investments and obtain flexible investment portfolios that include the penetration of conventional DG on distribution systems.

Evaluating the investment opportunitiesby limited data and

Black-Scho verifying the

les sensitivity analysis that shows the relationship between the value of developing RE and underlying assets ..

(Especially for thecase of REtechnology in Taiwan.)

Thermal power generating cost, deploying

Least An ability to sequence of options/identify cost,carbon Monte price, thermal Carlo any possibility of power with CCS (LSM) combining method. options

f

1




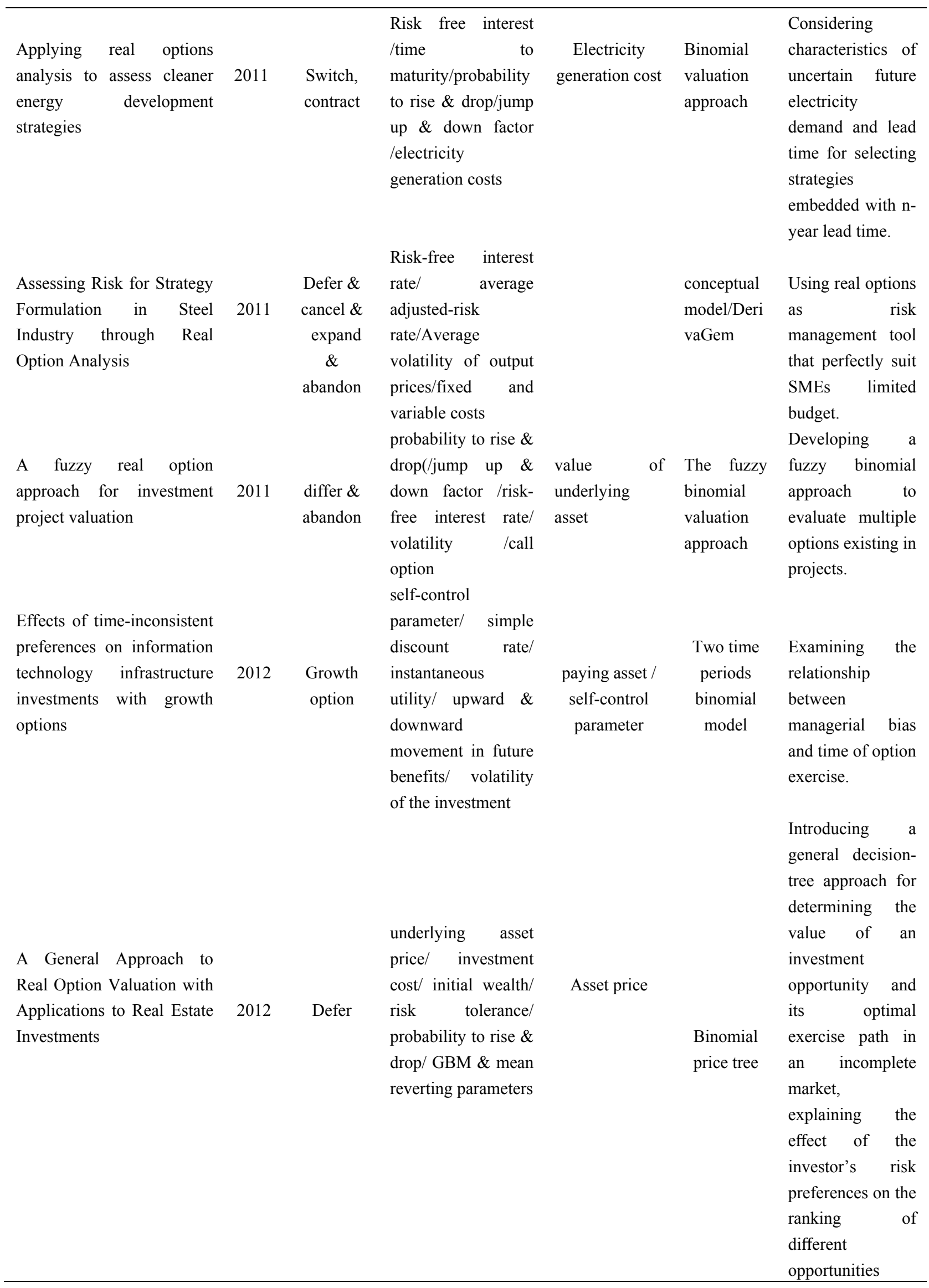




\section{Summary and Conclusions}

We review different factors affecting appraisal methods selection in a lot of survey conducted in several countries during several years and we show it briefly in table 6.1. Also reassess the most important problems in applying traditional methods mentioned by Adler and the way RO logic could remove them.

Table 6.1. Important criteria and factors on investment appraisal through empirical and theory studies

\begin{tabular}{|c|c|c|}
\hline $\begin{array}{l}\text { Important factors on appraisal method selection } \\
\text { through empirical research }\end{array}$ & $\begin{array}{l}\text { Author \& } \\
\text { year }\end{array}$ & $\begin{array}{l}\text { Required Criteria in investment through theory } \\
\text { studies }\end{array}$ \\
\hline Use of computer in capital budgeting & Pike 1996 & $\begin{array}{l}\text { Non- financial criteria, intangible, or } \\
\text { immeasurable factors }\end{array}$ \\
\hline Annual capital budget /capital budget size & Ryan 2002 & Life time of project \\
\hline Age of company & & Uncertainty \\
\hline Education and background of CFOs & & Managerial flexibility \\
\hline & $\begin{array}{l}\text { Leonet al } \\
\quad 2008\end{array}$ & \\
\hline $\begin{array}{l}\text { Overall objectives of the capital budgeting } \\
\text { process }\end{array}$ & & Active project management \\
\hline Multinational culture & $\begin{array}{l}\text { Andoret al } \\
2011\end{array}$ & $\begin{array}{l}\text { Cost, ease and time regarding to related capital } \\
\text { budget size and experts }\end{array}$ \\
\hline \multicolumn{3}{|l|}{ Foreign sale \& growth opportunity } \\
\hline & $\begin{array}{l}\text { Daunfeldt\&H } \\
\text { artwig } 2011\end{array}$ & \\
\hline $\begin{array}{l}\text { Choice of target debt ratio \& dividend payoff } \\
\text { ratio }\end{array}$ & & \\
\hline
\end{tabular}

Wereview the RO domain and its process to find that whether RO logic could be used for any cases. Then we over looktwo surveys which assessing RO adoption in different industries with noting the most important reasons of using or not using $\mathrm{RO}$ logic. The reasons are a lot about input data collection than functional limitations. However, due to lack of adoption, RO advantages could not be entirely found and also disadvantages.

An implication of this paper is that firms interested in adopting real options analysis must first provide the infrastructures: changing manager's mindset about the appropriate paradigm for evaluating projects (by hiring external consultant), required expertise (This level of expertise is needed not only by financial analysts but also by top management), smooth, organized process of sharing data and tools like user-friendly software which can handle the modeling complexity.

Nonetheless DCF techniques took decades to become routine in analyzing capital budgeting projects, (it emerged in 1900s and became prevalent among industries in 1980s \& 1990s). Considering the sophistication and complexity of real options, this approach is likely to experience a similar evolution.

Our hope in presenting thispaper is to provide both academics and practitioners with greater insight to the state of real option: representing the supporting role of RO as a complementary approach of traditional methods, reviewing reasons for an unsuccessful appraisal under real option gives us insight for removing most deterrent obstacles.

\section{References}

A.Ryan. Patricia., \& P. Ryan, Glenn. (2002), Capital Budgeting Practices of the Fortune 1000: How Have Things Changed? Journal of Business and Management, 8(4), winter.1-15.

Alexander. Carol., \& Chen. Xi. (2012). A General Approach to Real Option Valuation with Applications to Real Estate Investments. ICMA Centre Discussion Papers in Finance, January, HENLEY university of reading, $1-41$. 
Amram. M., \& Kulatilaka. N. (1999). Real Option: Managing Strategies Investment in an Uncertain World. Boston, Mass: Harvard Business School Press.

Andersen, Lars. (2002). How Options Analysis Can Enhance Managerial Performance. European Management Journal, 20(5), 505-511.

Andor, Gyorgy., Mohanty, Sunil.k., \& Toth, Tamas. (2011). Capital budgeting practices: a survey of central and eastern European firms. World bank, January, 1-45.

Baker. H. Kent, Dutta. Shantanu., \& Saadi. Samir. (2007). Management Views on Real Options in Capital Budgeting.

Block, Stanley. (2007). Are real options actually used in the real world?. The engineering economist, 52(3). http://dx.doi.org/10.1080/00137910701503910.265-267

Buzarquis, Enrique., \& A. Blanco. Gerardo. (2010). Valuing Investments in Distribution Networks with DG under Uncertainty. PES Transmission and Distribution Conference and Exposition: Latin America, IEEE. 341-348.

Chan. Hung, Haddad. Kamal. M., \& Sterk.William. (2001). Capital budgeting practices of Chinese firms.

Chen, Tao, Zhang, Jinlong., \& Lai, Kin-Keung. (2009). An integrated real options evaluating model for information technology projects under multiple risks. International Journal of Project Management, 27, 776-786.

Cheng, Ching-Tsung, Lo, Shang-Lien., \& Lin, Tyrone T. (2011). Applying real options analysis to assess cleaner $\begin{array}{lllllll}\text { energy development } & \text { strategies. Energy Policy, } & 39, & 5929 & -5938 .\end{array}$ http://dx.doi.org/10.1016/j.enpol.2011.06.048

Cortazar, Gonzalo, Gravet, Miguel., \& Urzua, Jorge. (2008). The valuation of multidimensional American real options using the LSM simulation method. Computers \& Operations Research, 35, 113-129. http://dx.doi.org/10.1016/j.cor.2006.02.016

Daunfeldt, Sven-Olov., \& Hartwig, Fredrik. (2011). What Determines the Use of Capital Budgeting Methods? Evidence from Swedish listed companies. Social Science Research Network, 1-37.

Dixit, A., \& Pindyck, R. (1994). Investment under uncertainty. Princeton university press.

Foss, N. J. (1998). Real options and the theory of the firm: Institut for IndustriøkonomogVirksomhedsstrategi, Handelshøjskolen i København.

Graham, John., \& Harvey, Campbell. (2001). How Do CFOS Make Capital Budgeting And Capital Structure Decisions?. Journal of applied corporate finance, 15(1), 8-23.

Ho, Shiu-Hwei., \& Liao, Shu-Hsien. (2011). A fuzzy real option approach for investment project valuation. Expert Systems with Applications, 38, 15296-15302. http://dx.doi.org/10.1016/j.eswa.2011.06.010

Kaplan, RS., \& Norton, DP. (1992). The balanced scorecard: measures that drive performance. Harvard Business Review, 70(1), 71-79.

Khan, Sarah S., Khouja, Moutaz., \& Kumar, Ram L. (2012). Effects of time-inconsistent preferences on information technology infrastructure investments with growth options. European Journal of Information Systems, 1-15.

Kodukula, Prasad., \& Papudesu, PMP Chandra. (2006). Project Valuation Using Real Options: A Practitioner's Guide. J. Ross Publishing, U.S.A.

Krychowski, Chalotte., \& V. Quelin, Bertrand. (2010). Real option and strategic investment decisions: can they be of use to scholars?, Academy of management perspectives, 65-77.

Lee, Shun-Chung. (2011). Using real option analysis for highly uncertain technology investments: The case of wind energy technology. Renewable and Sustainable Energy Reviews, July(32), 1-8. http://dx.doi.org/10.1016/j.rser.2011.07.107

Leon. Farah M., Isa. Mansor., \& Kester. George W. (2008). Capital Budgeting Practices of Listed Indonesian Companies. Asian Journal of Business and Accounting, 1(2), 175-192.

Liljeblom, Eva., \& Vaihekoski, Mika. (2004). Investment evaluation methods and required rate of return in Finnish publicly listed companies. January, 1-24.

Mao, James. (1970). Survey of capital budgeting: theory and practice. The journal of finance, May, 25(2), 
349-360.

Milis, Koen., Snoeck, Monique., \& Haesen, Raf. (2008). Evaluation of the applicability of investment appraisal techniques for assessing the business value of IS services. Katholikeuniversiteit Leuven, Faculty of Business and Economics, Department of decision science and information management (KBI).

Muharam. Farrah Merlinda, (2011), Assessing Risk for Strategy Formulation in Steel Industry through Real Option Analysis, 7th International Strategic Management Conference. Procedia Social and Behavioral Sciences, 24, 991-1002. http://dx.doi.org/10.1016/j.sbspro.2011.09.080

Mun, Johnathan. (2002). Real Options Analysis Tools and Techniques for Valuing Strategic Investments and Decisions. John Wiley \& Sons, New Jersey.

Partington, D. (2000). Implementing strategy through programs of projects. In: Turner JR, Simister SJ, editors, Gower handbook of project management (3rd ed.). UK: Gower Publishing Ltd. 33-46.

Pike, Richard. (1996). A longitudinal survey on capital budgeting practices. Journal of business finance \& accounting, 23(1), 79-92.

Ross, Marc. (1986). Capital Budgeting Practices of Twelve Large Manufacturers. Financial Management, winter, capital budgeting practices, 15(4), 15-22.

Sangster, Alan. (1993). Capital investment appraisal techniques: A survey of current usage. Journal of Business Finance \& Accounting, 20(3), 307-332.

Soni, Kashyap. (2006). Capital budgeting practices in India. PhD. dissertation. Nottingham university business school, University of Nottingham.

W. Adler. Ralph. (2000). Strategic Investment Decision Appraisal Techniques: The Old and the New. Business Horizons, December, 15-22.

Wang, Zhen., \& Tang, Xin. (2010). Research of Investment Evaluation of Agricultural Venture Capital Project on Real Options Approach, International Conference on Agricultural Risk and Food Security 2010. Agriculture and Agricultural Science Procedia, 1, 449-455. http://dx.doi.org/10.1016/j.aaspro.2010.09.056

Wang. Chung-Hsiao., \& Min. K. Jo. (2006). Electric Power Generation Planning for Interrelated Projects: A Real Options Approach. Transactions on engineering management, 53(2), 312-322. http://dx.doi.org/10.1109/TEM.2006.872249

Zhu, Lei., \& Fan, Ying. (2011). A real options-based CCS investment evaluation model: Case study of China's power generation sector. Applied Energy, 88, 4320-4333. http://dx.doi.org/10.1016/j.apenergy.2011.04.005 